\title{
Improved productivity of poly (4-hydroxybutyrate) (P4HB) in recombinant Escherichia coli using glycerol as the growth substrate with fed-batch culture
}

Sylvaine Le Meur ${ }^{1,2}$, Manfred Zinn ${ }^{1,3}$, Thomas Egli ${ }^{2,4}$, Linda Thöny-Meyer ${ }^{1}$ and Qun Ren ${ }^{1 *}$

\begin{abstract}
Background: The most successful polyhydroxyalkanoate (PHA) in medical applications is poly(4-hydroxybutyrate) (P4HB), which is due to its biodegradability, biocompatibility and mechanical properties. One of the major obstacles for wider applications of $\mathrm{P} 4 \mathrm{HB}$ is the cost of production and purification. It is highly desired to obtain P4HB in large scale at a competitive cost.
\end{abstract}

Results: In this work, we studied the possibility to increase P4HB productivity by using high cell density culture. To do so, we investigated for the first time some of the most relevant factors influencing P4HB biosynthesis in recombinant Escherichia coli. We observed that P4HB biosynthesis correlated more with limitations of amino acids and less with nitrogen depletion, contrary to the synthesis of many other types of PHAs. Furthermore, it was found that using glycerol as the primary carbon source, addition of acetic acid at the beginning of a batch culture stimulated P4HB accumulation in E. coli. Fed-batch high cell density cultures were performed to reach high P4HB productivity using glycerol as the sole carbon source for cell growth and $4 \mathrm{HB}$ as the precursor for $\mathrm{P} 4 \mathrm{HB}$ synthesis. A P4HB yield of $15 \mathrm{~g} \mathrm{~L}^{-1}$ was obtained using an exponential feeding mode, leading to a productivity of $0.207 \mathrm{~g} \mathrm{~L}^{-1}$ $\mathrm{h}^{-1}$, which is the highest productivity for P4HB reported so far.

Conclusions: We demonstrated that the NZ-amines (amino acids source) in excess abolished P4HB accumulation, suggesting that limitation in certain amino acid pools promotes P4HB synthesis. Furthermore, the enhanced P4HB yield could be achieved by both the effective growth of E. coli JM109 (pKSSE5.3) on glycerol and the stimulated P4HB synthesis via exogenous addition of acetic acid. We have developed fermentation strategies for P4HB production by using glycerol, leading to a productivity of $0.207 \mathrm{~g} \mathrm{~L}^{-1} \mathrm{~h}^{-1}$ P4HB. This high P4HB productivity will decrease the total production cost, allowing further development of P4HB applications.

Keyword: P4HB, High cell density culture, Glycerol, Acetic acid, Recombinant E. coli, Fed batch, Productivity

\section{Background}

Polyhydroxyalkanoates (PHAs) are natural polyesters that have gained special interest due to their biodegradability and biocompatibility [1-4]. PHAs can be stored by a wide variety of microorganisms as intracellular reserve materials. They are accumulated when the bacterial cells experience nutrient-limited growth conditions other than

\footnotetext{
* Correspondence: qun.ren@empa.ch

'Laboratory for Bioactive Materials, Swiss Federal Laboratories for Materials Science and Technology (Empa), Lerchenfeldstrasse 5, St. Gallen CH-9014, Switzerland

Full list of author information is available at the end of the article
}

carbon. Up to now, more than a hundred different monomers have been reported to be incorporated as building blocks into bacterial PHAs, resulting in different material properties of the polymers [5-8].

One of the most promising PHAs for medical applications is poly(4-hydroxybutyrate) (P4HB) [9]. This homopolymer is a strong and flexible material, which can be employed for instance for tissue engineering and drug delivery. In addition, P4HB is biocompatible and extremely well tolerated in vivo due to the fact that hydrolysis of $\mathrm{P} 4 \mathrm{HB}$ yields $4 \mathrm{HB}$, which is a common metabolite in the 
human body [10]. This biopolymer was the first - and so far only - PHA-based material approved for clinical application as absorbable suture (TephaFLEX ${ }^{\oplus}$ by the FDA. Other applications of $\mathrm{P} 4 \mathrm{HB}$ are currently under investigation, for example, Opitz and coworkers successfully produced an ovine, aortic blood vessel substitute using bioabsorbable P4HB scaffolds [11]. However, the high cost of P4HB hinders its wider applications [2]. In order to have sufficient material available for application studies and to reduce production cost, much research has been focused on the efficient production of $\mathrm{P} 4 \mathrm{HB}$ by increasing the amount of biopolymer accumulated in the cells. Surprisingly, there are no reports found in the literature documenting the use of high cell density (higher than $20 \mathrm{~g} \mathrm{~L}^{-1}$ ) processes to reach high $\mathrm{P} 4 \mathrm{HB}$ productivities. High productivity can be obtained by combining cultivation procedures to achieve maximum polymer accumulation per cell with those allowing fast growth to reach high cell densities. High cell density processes allow increasing the productivity of accumulated metabolites with simultaneously decreasing the production cost as a result of a lower culture volume (smaller bioreactors) and shorter fermentation time. So far there is no generally accepted value to be defined as high cell density [12]. Different studies have considered different values of cell dry weight (CDW), for example, Restaino and coworkers reported a high cell density of $22 \mathrm{~g}$ CDW per liter for Escherichia coli culture [13], whereas Yamanè and Shimizu mentioned that high cell density cultivation is achieved when reaching about cell concentrations of $50 \mathrm{~g}$ CDW per liter [14].

Generally, high cell densities are reached by fed-batch cultures using a pulse, linear or exponential feed of the limiting carbon substrate. It was reported that exponential feeding allows to achieve cell concentrations up to $148 \mathrm{~g} \mathrm{~L}^{-1}$ using glycerol as carbon source with $E$ coli TG1 cells [15]. To increase productivity, it is important to understand the factors stimulating $\mathrm{P} 4 \mathrm{HB}$ accumulation. In earlier work using recombinant $E$. coli, we identified three physiological phases during $\mathrm{P} 4 \mathrm{HB}$ production: i) the "growth phase", in which cells grew exponentially, ii) the "accumulation phase", in which cells stopped dividing and started to accumulate $\mathrm{P} 4 \mathrm{HB}$, and iii) the "stagnation phase", in which both cell proliferation and P4HB accumulation stopped while the total biomass remained constant [16]. Hence, under this condition P4HB synthesis was found to be distinctly separated from cell growth and to occur after exponential cell growth stopped. This is different from the synthesis of other types of PHAs in recombinant E. coli $[3,17]$.

While the development of a highly efficient fermentation process constitutes one part of the optimization procedure, the use of a cheap carbon substrate is another crucial factor that allows reducing production costs significantly.
For example, the hemicellulose derivative xylose can be used as an industrially relevant carbon source for growth of E. coli strains in general [18] and for P4HB homopolymer production in particular [16]. Glycerol is another interesting carbon source because it currently accumulates as a waste byproduct during biodiesel production [19], and therefore, production of higher value products from crude glycerol is of primary interest. Glycerol, which can be used both as carbon and energy source, enables cheap production of valuable synthons, for example 1,3-propanediol, dihydroxyacetone, ethanol, succinate, and propionate [20] and has been tested as growth substrate for E. coli in fed-batch processes to reach high cell density [21]. Advancements in metabolic engineering made it possible to produce many heterologous products such as proteins [22], biofuels [23], and PHAs [2,3] in E. coli strains at high cell density. A recent study demonstrated that crude and refined glycerol from biodiesel industry can be used as carbon substrate to accumulate mediumchain-length PHAs by Pseudomonas mediterranea and P. corrugate [24].

In this study we investigated the influence of different nutrient concentrations on P4HB synthesis in E. coli JM109 (pKSSE5.3), a strain harboring the genes essential for $\mathrm{P} 4 \mathrm{HB}$ production from $4 \mathrm{HB}$. We further tested whether or not refined glycerol can be used as the growth substrate for $\mathrm{P} 4 \mathrm{HB}$ production in high cell density cultures. It was found that acetate can stimulate $\mathrm{P} 4 \mathrm{HB}$ synthesis in recombinant E. coli grown on glycerol. Based on this study, an efficient process was developed to reach high productivity of $\mathrm{P} 4 \mathrm{HB}$ by using high cell density cultures combined with acetic acid addition.

\section{Results and discussion}

Previously, we observed that the recombinant E. coli strain JM109 (pKSSE5.3) synthesized only small amount of P4HB (about 10\%) when glycerol was offered as carbon source [16]. In this study, we attempted to utilize this inexpensive carbon source as the growth substrate for $\mathrm{P} 4 \mathrm{HB}$ synthesis by high cell density cultivation. To enhance $\mathrm{P} 4 \mathrm{HB}$ production, we first set out to identify the influencing factors for $\mathrm{P} 4 \mathrm{HB}$ synthesis. It is difficult to conclude whether a factor plays a significantly influencing role or not when the base value is low such as $10 \%$, especially when the factor has negative impact. Thus, xylose, which could lead to $30-70 \%$ P4HB [16], was used as the growth carbon source for the investigation.

\section{Identification of factors influencing P4HB synthesis}

E. coli JM109 (pKSSE5.3) was cultivated in $1 \mathrm{~L}$ bioreactors containing modified E2 minimal medium. Various factors were tested for their influence on P4HB synthesis: carbon, nitrogen and amino acid source, trace elements and magnesium. As described previously [16], three phases (growth, 
accumulation and stagnation phase) were observed for cultures A (with standard medium containing modified $\mathrm{E} 2$ medium $+10 \mathrm{~g} \mathrm{~L}^{-1}$ xylose $+4 \mathrm{~g} \mathrm{~L}^{-1} \mathrm{Na}-4 \mathrm{HB}+1 \mathrm{~g} \mathrm{~L}^{-1}$ $\mathrm{NZ}$-amines $+1 \mathrm{~mL} \mathrm{~L}^{-1}$ trace elements), $\mathrm{B}$ (two times more xylose), $\mathrm{C}$ (five times more nitrogen source $\mathrm{NaNH}_{4} \mathrm{HPO}_{4}$. $4 \mathrm{H}_{2} \mathrm{O}$ ), E (three times more trace elements), and $\mathrm{F}$ (three times more magnesium), whereas culture $\mathrm{D}$ (five times more NZ-amines) exhibited no accumulation phase (Figure 1). Culture D reached a maximal $\mathrm{OD}_{600}$ and a maximal P4HB content of about 8.6 and $3 \%\left(\mathrm{w} \mathrm{w}^{-1}\right)$, respectively. Culture $A$ with the standard medium led to highest maximal $\mathrm{P} 4 \mathrm{HB}$ content of $65 \%\left(\mathrm{w} \mathrm{w}^{-1}\right)$, while Cultures B, C, E and F reached a slightly lower maximal P4HB content of $52 \%, 52 \%, 59 \%, 45 \%$, respectively.

These results showed that NZ-amines (amino acids) in excess blocked $\mathrm{P} 4 \mathrm{HB}$ synthesis, whereas increased concentrations of carbon source, nitrogen source $\mathrm{NaNH}_{4} \mathrm{HPO}_{4}$. $4 \mathrm{H}_{2} \mathrm{O}$, trace elements or magnesium did not impact $\mathrm{P} 4 \mathrm{HB}$ synthesis significantly. Normally, PHAs accumulate in the bacterial growth phase under nitrogen, phosphorous or oxygen limited conditions with an excess of carbon source $[4,25]$. It has been reported that recombinant $E$. coli does not require any nutrient limitation for synthesis of poly(3-hydroxybutyrate) (P3HB) and produces $\mathrm{P} 3 \mathrm{HB}$ in a growth-associated manner even under nutrient-sufficient conditions [17]. In this study with a recombinant E. coli strain, neither nitrogen nor carbon source in excess led to a significant reduction of $\mathrm{P} 4 \mathrm{HB}$ content, whereas excess of amino acids (NZ-amines) almost abolished P4HB synthesis (Figure 1). It seems that amino acid limitation caused a halt of cell growth and triggered $\mathrm{P} 4 \mathrm{HB}$ accumulation.

Previously, we have tested a defined medium without addition of any amino acid for P4HB synthesis and found that the chemically defined medium resulted in hardly any $\mathrm{P} 4 \mathrm{HB}$ synthesis [26]. Addition of a small amount of complex nitrogen sources such as NZ-amines

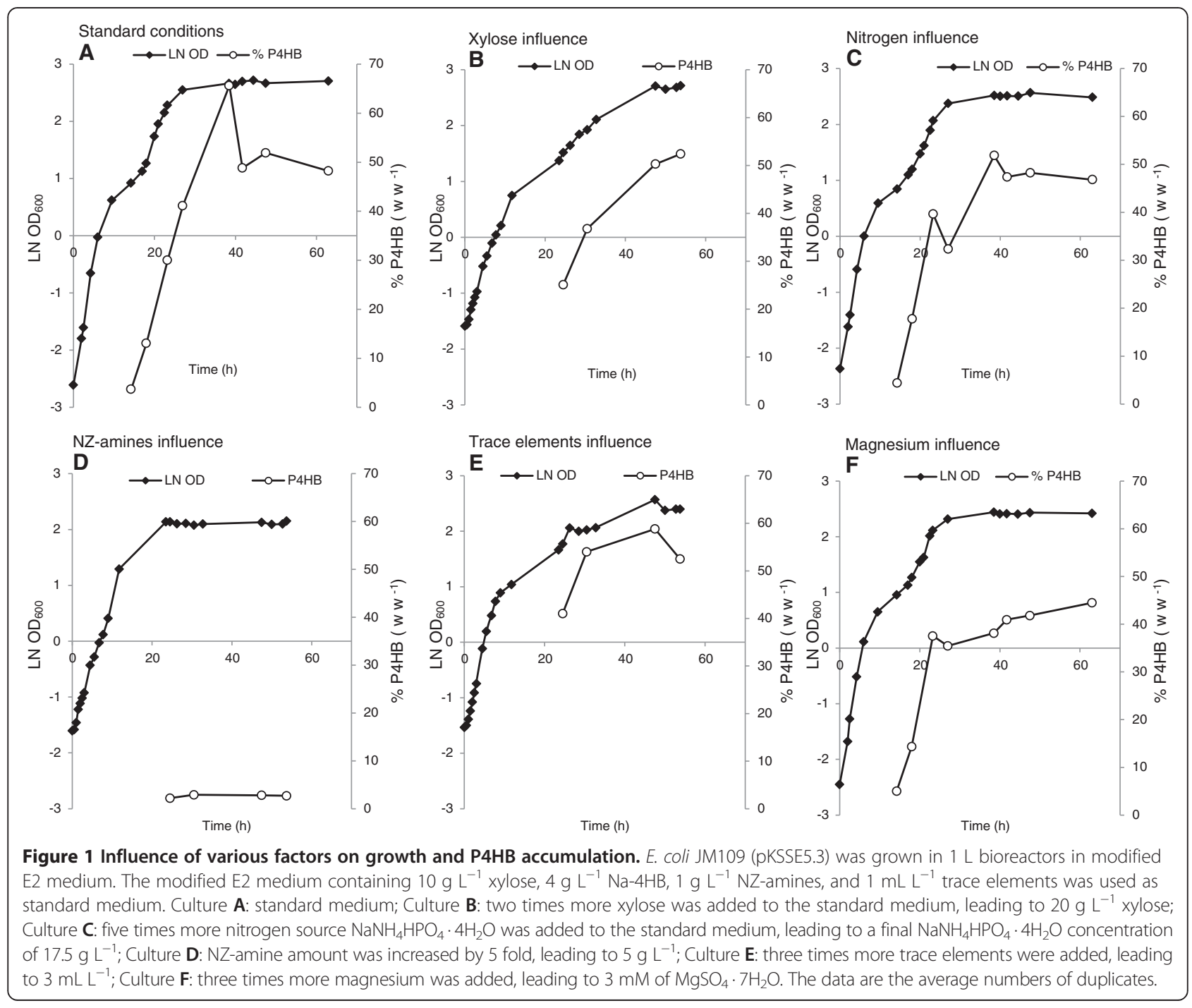


promoted considerably $\mathrm{P} 4 \mathrm{HB}$ accumulation [26]. Therefore, other means than omitting amino acid in the medium are needed to limit the intracellular amino acid concentration for promoting $\mathrm{P} 4 \mathrm{HB}$ synthesis.

\section{Influence of acetate on P4HB synthesis}

To artificially obtain amino acid limitation, one possibility is to add weak organic acids to the culture medium. It has been reported that the growth inhibitory effect of acetic acid on E. coli is due to its influence on the amino acid (e.g. methionine) pool in the cells: the more acetic acid produced, the smaller the methionine pool becomes, leading to restriction of cell growth [27]. Recently we have reported that addition of propionic acid to the culture medium stimulates $\mathrm{P} 4 \mathrm{HB}$ accumulation in recombinant $E$. coli grown on glycerol. This stimulating effect was significantly weakened by addition of exogenous methionine but not by cysteine, suggesting that propionic acid enhances $\mathrm{P} 4 \mathrm{HB}$ synthesis at least partially by reducing the intracellular methionine pool [26]. Whether propionic acid also influences other amino acids pools is not investigated, thus not known. In this study, we further investigated whether the extracellular addition of acetic acid would enhance $\mathrm{P} 4 \mathrm{HB}$ synthesis. Glycerol is a simple polyol compound and a side product from the biodiesel industries. E. coli grown on glycerol generates lower amounts of acetic acid than on xylose or glucose $[15,28]$. E. coli JM109 (pKSSE5.3) was grown in $1 \mathrm{~L}$ shake flasks containing modified E2 medium. A concentration of $10 \mathrm{~g} \mathrm{~L}^{-1}$ of glycerol was added with or without $2 \mathrm{~g} \mathrm{~L}^{-1}$ acetic acid at the beginning of the cultivation. With acetic acid a maximal content of $23 \% \mathrm{w} \mathrm{w}^{-1} \mathrm{P} 4 \mathrm{HB}$ was obtained, whereas without only $12 \% \mathrm{w} \mathrm{w}^{-1}$ was achieved (Figure $2 \mathrm{~A}$ ). To confirm that the observed enhanced $\mathrm{P} 4 \mathrm{HB}$ content was not caused by a reduced growth rate due to the addition of acetic acid, $1 \mathrm{~g} \mathrm{~L}^{-1}$ instead of $2 \mathrm{~g} \mathrm{~L}^{-1}$ acetic acid was added at the beginning of the cultivation on glycerol. The cultures with or without $1 \mathrm{~g} \mathrm{~L}^{-1}$ acetic acid showed the same growth rate of $0.31 \mathrm{~h}^{-1}$ (Figure 2B); however, the culture with addition of acetic acid accumulated much more P4HB than the one without (Figure 2B). Thus, it can be speculated that the P4HB synthesis is stimulated by acetic acid addition through reduction of the intracellular amino acid pool rather than a reduction in specific growth rate, similar to the findings reported previously [26].

Previously, it has been reported that the molar fraction of $4 \mathrm{HB}$ in the $\mathrm{P}(3 \mathrm{HB}-c o-4 \mathrm{HB})$ biosynthesis by $R$. eutropha was increased significantly from 38 to $54 \mathrm{~mol} \%$ by the addition of a small amount of acetic acid or propionate [29]. The authors suggested that acetate is able to increase acetyl-CoA pool, inhibit the ketolysis of 4-hydroxybutyrylCoA to two molecules of acetyl-CoA, and consequently increase $4 \mathrm{HB}$ fraction. If this hypothesis is valid for $E$. coli, E. coli (pKSSE5.3) would be able to utilize $4 \mathrm{HB}$ as a sole carbon source for cell growth. However, E. coli JM109 (pKSSE5.3) is not able to grow on medium containing $4 \mathrm{HB}$ as the sole carbon source and cannot use $4 \mathrm{HB}$ as a growth substrate even when combined with another growth C-source [16]. Furthermore, we have recently showed that propionic acid enhances $\mathrm{P} 4 \mathrm{HB}$ synthesis by reducing the intracellular methionine pool [26]. Therefore, the hypothesis that addition of acetate stabilizes 4hydroxybutyryl-CoA from ketolysis and consequently
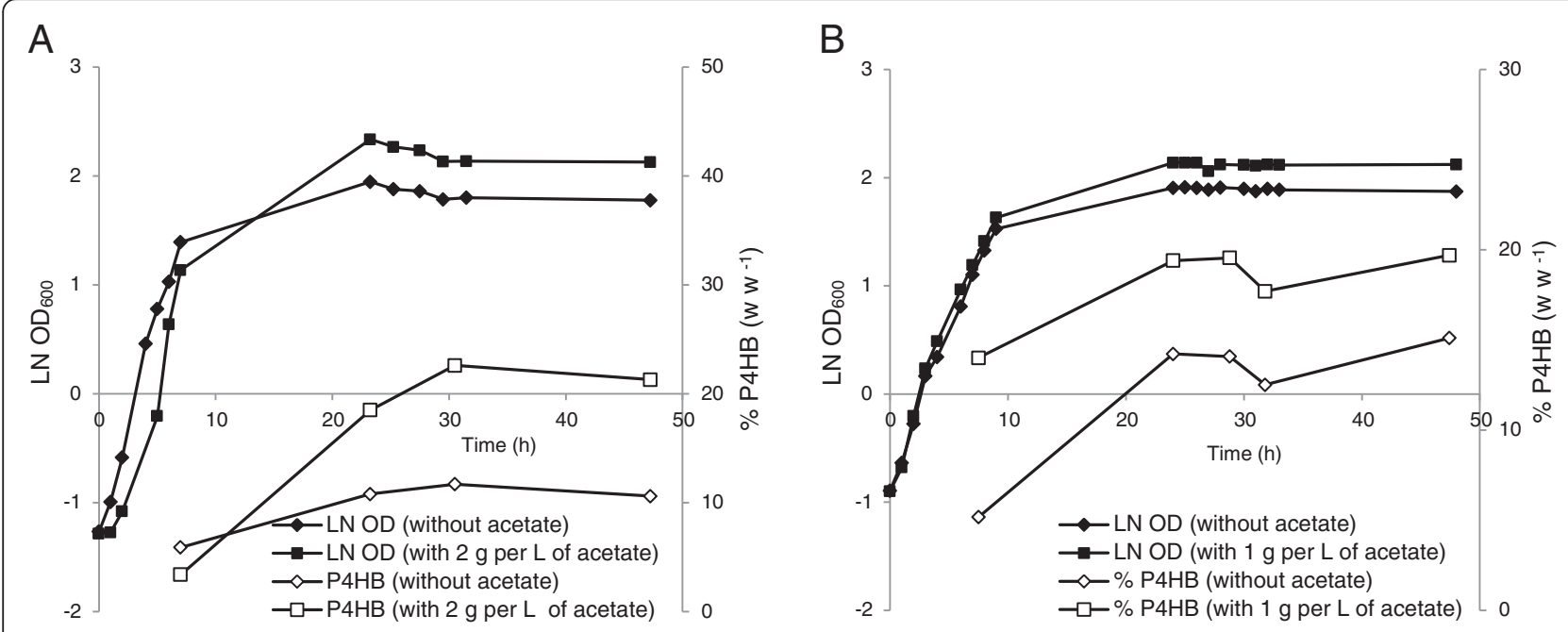

Figure 2 E. coli JM109 (pKSSE5.3) grown in modified E2 medium supplemented with or without acetate in shake flasks. $10 \mathrm{~g} \mathrm{~L}^{-1}$ glycerol was used as the main carbon source. A: $2 \mathrm{~g} \mathrm{~L}^{-1}$ acetate was added to the culture; $\mathbf{B}$ : $1 \mathrm{~g} \mathrm{~L}^{-1}$ acetate was added to the culture. The data are the average numbers of duplicates. 
leads to a higher 4HB fraction in polymers is not valid here. The results obtained further confirmed the hypothesis reported in our previous work [16] that the pathways for cell growth and $\mathrm{P} 4 \mathrm{HB}$ synthesis compete with each other. When the available nutrients and energy are used for cell growth, P4HB can hardly be synthesized. When the cell growth slows down/stops due to nutrient limitation (e.g. amino acids) other than carbon starvation, P4HB synthesis can be initiated. It has been reported that exogenous addition of acetic acid increases the acetyl-CoA synthetase (ACS) activity in order to reach the equilibrium between the concentration of acetate and acetyl-CoA [30]. An overflow of acetyl-CoA, which is the the donor of CoA to $4 \mathrm{HB}$, increases the accumulation of $\mathrm{P} 4 \mathrm{HB}$.
Influence of acetate addition on P4HB synthesis at different physiological growth stages

The influence of acetic acid addition at different physiological growth stages was studied during high cell density cultivation. E. coli JM109 (pKSSE5.3) was grown on modified M9 medium. Glycerol and Na-4HB were pulsed when needed during cell growth, which was indicated by an increase of dissolved oxygen tension $\left(\mathrm{pO}_{2}\right)$ signal. In culture A (Figure 3), $2 \mathrm{~g} \mathrm{~L}^{-1}$ of acetic acid was added at the beginning of the cultivation. The cells reached a maximal $\mathrm{OD}_{600}$ of 57.5 with a $\mathrm{P} 4 \mathrm{HB}$ content of $31 \% \mathrm{w} \mathrm{w}^{-1}$ at $64 \mathrm{~h}$ of cultivation. In culture $\mathrm{B}, 1 \mathrm{~g} \mathrm{~L}^{-1}$ acetic acid was added twice, first at the beginning and again at the end of the growth phase $(66 \mathrm{~h})$. The cells reached a maximal $\mathrm{OD}_{600}$ of 92.6 with a $\mathrm{P} 4 \mathrm{HB}$ content of $30 \% \mathrm{w} \mathrm{w}^{-1}$ at $63 \mathrm{~h}$. In

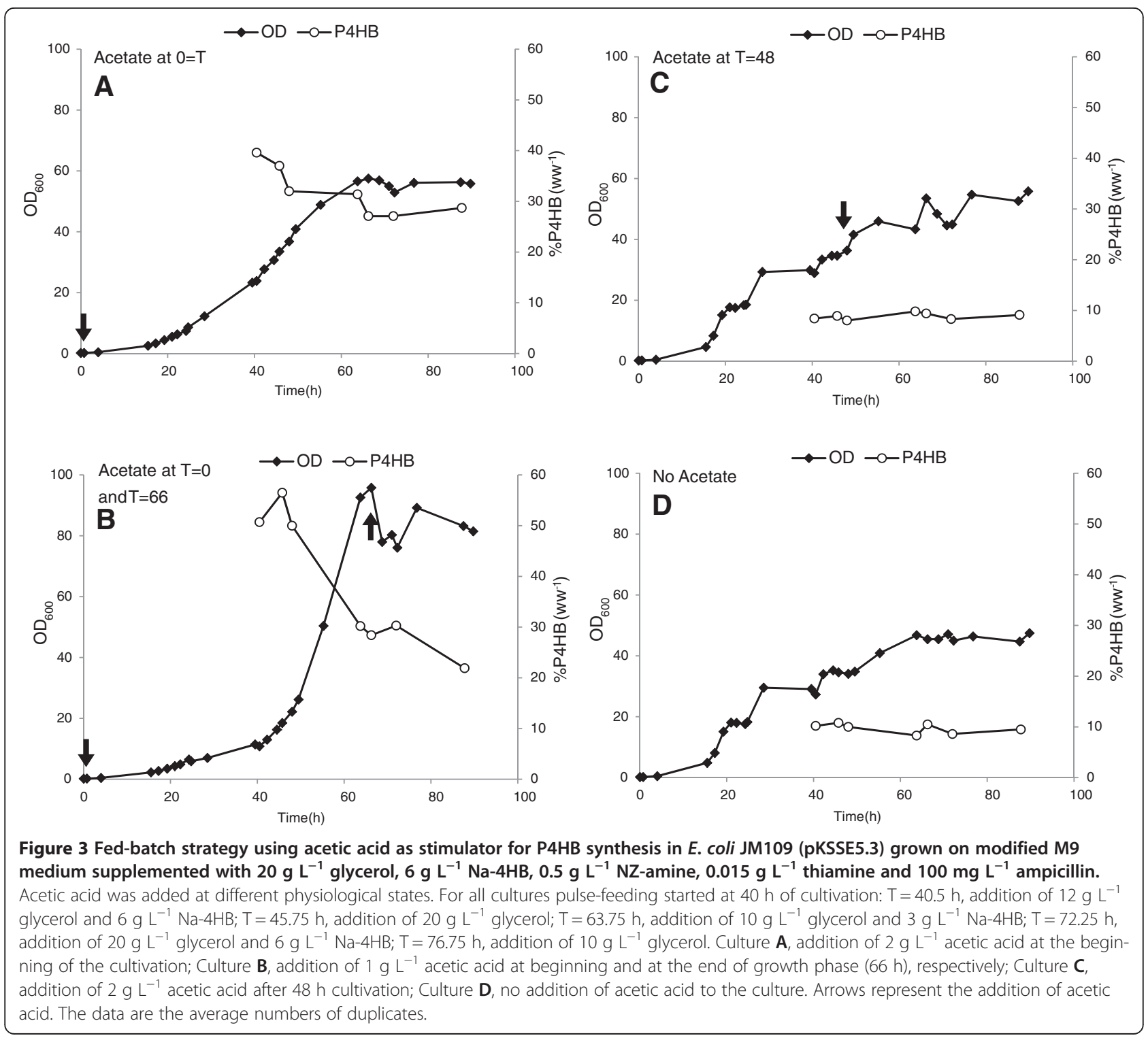


culture C, $2 \mathrm{~g} \mathrm{~L}^{-1}$ acetic acid was added at $48 \mathrm{~h}$ of cultivation. The cells reached a maximal $\mathrm{OD}_{600}$ of 53.5 at $66.25 \mathrm{~h}$ with a $\mathrm{P} 4 \mathrm{HB}$ content of $9 \% \mathrm{w} \mathrm{w}^{-1}$. The culture without any addition of acetic acid (culture D) reached a maximal $\mathrm{OD}_{600}$ of 45.5 with a $\mathrm{P} 4 \mathrm{HB}$ content of $10 \%$ $\mathrm{w} \mathrm{w}^{-1}$ (Figure 3). These results demonstrated that the addition of acetic acid at the beginning of the cultivation enhances $\mathrm{P} 4 \mathrm{HB}$ accumulation dramatically, leading to a three-fold higher $\mathrm{P} 4 \mathrm{HB}$ content than without acetic acid. The addition of acetic acid at the end of the exponential growth phase did not result in any improvement of $\mathrm{P} 4 \mathrm{HB}$ production compared to the culture without any acetic acid.

The reason why addition of acetic acid at the end of growth phase did not promote P4HB synthesis could be that cell metabolism at the stationary phase is not active enough to convert acetic acid to acetyl-CoA. When acetic acid is added at the beginning of the growth phase, it can be converted to acetyl-CoA which can be further channeled to cell growth and maintenance (during the growth phase) or $\mathrm{P} 4 \mathrm{HB}$ synthesis (during the accumulation phase).

\section{Influence of the feeding mode on P4HB product during fed-batch culture}

Based on the above results, different nutrient feeding strategies were compared for $\mathrm{P} 4 \mathrm{HB}$ production in recombinant E. coli JM109 (pKSSE5.3) using glycerol as the carbon substrate and acetic acid as the stimulator.

\section{Pulse-feeding}

The batch culture was performed using modified M9 medium. Glycerol, Na-4HB and acetic acid were added when the carbon source glycerol was limited. Glycerol limitation was monitored by pO2 signal as described in Materials and Methods. This culture grew with an initial specific growth rate of $0.11 \mathrm{~h}^{-1}$ (Figure 4). The concentration of $\mathrm{Na}-4 \mathrm{HB}$ was never limiting and did not exceed $7 \mathrm{~g} \mathrm{~L}^{-1}$. The maximal $\mathrm{Na}-4 \mathrm{HB}$ consumption rate was $0.43 \mathrm{~g} \mathrm{~L}^{-1} \mathrm{~h}^{-1}$, leading to a maximal specific consumption

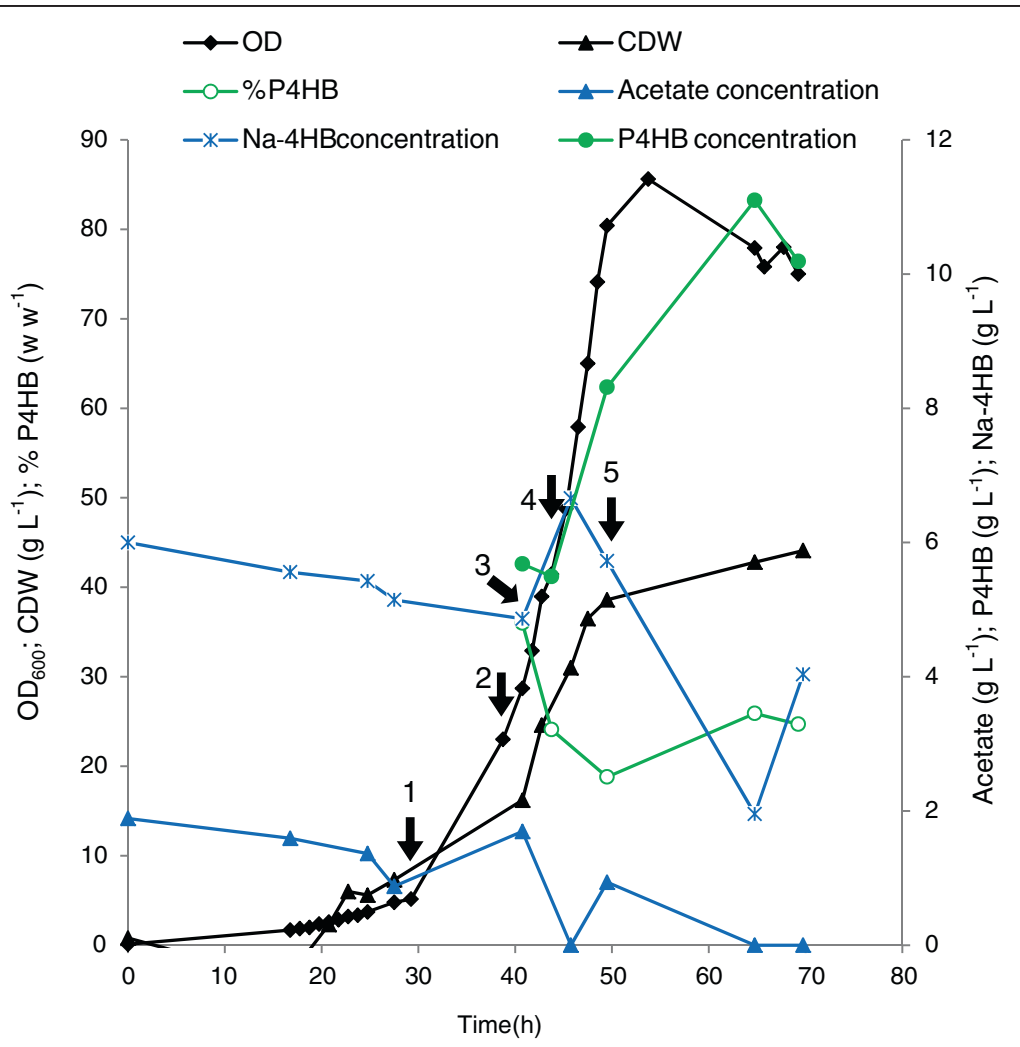

Figure 4 Time course of cell dry weight (CDW), P4HB content and P4HB concentration during a pulse feeding fed-batch culture of E. coli JM109 (pKSSE5.3). Glycerol and 4-hydroxybutyric acid were used as carbon source and precursor, respectively. Cultivation was conducted at $32^{\circ} \mathrm{C}$ in a $1 \mathrm{~L}$ bioreactor with an initial volume of $600 \mathrm{~mL}$ of modified $\mathrm{M} 9$ medium plus $20 \mathrm{~g} \mathrm{~L}^{-1}$ glycerol, $6 \mathrm{~g} \mathrm{~L}^{-1} \mathrm{Na}-4 \mathrm{HB}, 2 \mathrm{~g} \mathrm{~L}^{-1}$ acetic acid, $0.5 \mathrm{~g} \mathrm{~L}^{-1} \mathrm{NZ}$-amines, $0.015 \mathrm{~g} \mathrm{~L}^{-1}$ thiamine and $100 \mathrm{mg} \mathrm{L}^{-1}$ ampicillin. Feeding solution was added to the bioreactor when glycerol in the medium was close to depletion, indicated by $\mathrm{pO}_{2}$ signal. Arrow \#1, feeding of $12.5 \mathrm{~g} \mathrm{~L}^{-1}$ glycerol $+2.5 \mathrm{~g} \mathrm{~L}^{-1} \mathrm{Na}-4 \mathrm{HB}+1.1 \mathrm{~g} \mathrm{~L}^{-1}$ acetate at $30 \mathrm{~h}$; Arrow \#2, feeding of $25.0 \mathrm{~g} \mathrm{~L}^{-1}$ glycerol + $2.1 \mathrm{~g} \mathrm{~L}^{-1}$ acetate at $39 \mathrm{~h}$; Arrow \#3, feeding of $2.5 \mathrm{~g} \mathrm{~L}^{-1} \mathrm{Na}-4 \mathrm{HB}$ at $41 \mathrm{~h}$; Arrow \#4, feeding of $25.0 \mathrm{~g} \mathrm{~L}^{-1} \mathrm{glycerol}+2.1 \mathrm{~g} \mathrm{~L}$ acetate $+2.5 \mathrm{~g} \mathrm{~L}^{-1} \mathrm{Na}-4 \mathrm{HB}$ at $44 \mathrm{~h}$; Arrow $\# 5$, feeding of $25.0 \mathrm{~g} \mathrm{~L}^{-1}$ glycerol $+2.1 \mathrm{~g} \mathrm{~L}^{-1}$ acetate $+6 \mathrm{~g} \mathrm{~L}^{-1} \mathrm{Na}-4 \mathrm{HB}$ at $49.5 \mathrm{~h}$. The data are the average numbers of duplicates. 
rate of $0.05 \mathrm{~g} \mathrm{~g}^{-1} \mathrm{~h}^{-1}$. The initially fed acetic acid was not totally consumed when the first pulse of acetic acid was added to the culture broth after $30 \mathrm{~h}$ of cultivation. No visible impact on the cell growth was observed after this addition. After $39 \mathrm{~h}$ of cultivation, acetic acid was added once more, which was consumed quickly with a specific consumption rate of $0.032 \mathrm{~g} \mathrm{~g}^{-1} \mathrm{~h}^{-1}$. The P4HB content decreased after $40 \mathrm{~h}$ of cultivation along with the cell growth. However, the $\mathrm{P} 4 \mathrm{HB}$ concentration continuously increased, for example, during $9 \mathrm{~h}$ of cultivation from $40 \mathrm{~h}$ to $49 \mathrm{~h} 2.63 \mathrm{~g} \mathrm{~L}^{-1} \mathrm{P} 4 \mathrm{HB}$ was accumulated, leading to a P4HB accumulation rate of $0.25 \mathrm{~g} \mathrm{~L}^{-1} \mathrm{~h}^{-1}$. The $\mathrm{OD}_{600}$ increased continuously to 86 within $53 \mathrm{~h}$, afterwards decreased to 75 during prolonged cultivation from $53 \mathrm{~h}$ to $69 \mathrm{~h}$ (Figure 4).

\section{Linear-feeding}

The cells were grown in modified M9 medium. A feeding solution containing $200 \mathrm{~g} \mathrm{~L}^{-1}$ acetic acid and $200 \mathrm{~g} \mathrm{~L}^{-1}$ glycerol was used for the first $65 \mathrm{~h}$ of cultivation and then exchanged with a feeding solution of $100 \mathrm{~g} \mathrm{~L}^{-1}$ acetic acid and $400 \mathrm{~g} \mathrm{~L}^{-1}$ glycerol for the next $69 \mathrm{~h}$. Different feed rates were compared: $0.5,1,2$ and $3 \mathrm{~mL} \mathrm{~h}^{-1}$. It was found that the best feed rate for P4HB synthesis was between 1 and $2 \mathrm{~mL} \mathrm{~h}^{-1}$ under the conditions used in this study.
Below or above this range P4HB content decreased. Thus, the feed rates of 1 and $2 \mathrm{~mL} \mathrm{~h}^{-1}$ were studied in more details.

Figure 5 shows that with the feeding rate of $1 \mathrm{~mL} \mathrm{~h}^{-1}$ (Culture $\mathrm{A}$ ) the cells reached a maximal $\mathrm{OD}_{600}$ value of 63.8, a CDW of $22.4 \mathrm{~g} \mathrm{~L}^{-1}$ and a P4HB content of $30 \%$ $\mathrm{w} \mathrm{w}^{-1}$ after $119 \mathrm{~h}$, leading to a product concentration of about $7 \mathrm{~g} \mathrm{~L}^{-1} \mathrm{P} 4 \mathrm{HB}$. In Culture $\mathrm{B}$ (feeding rate of $2 \mathrm{~mL} \mathrm{~h}^{-1}$ ), the cells reached a maximal $\mathrm{OD}_{600}$ value, a CDW and a P4HB content of $80.9,32.9 \mathrm{~g} \mathrm{~L}^{-1}$, and $19 \%$ $\mathrm{w} \mathrm{w}^{-1}$ after $119 \mathrm{~h}$, respectively, leading to a yield of about $6 \mathrm{~g} \mathrm{~L}^{-1} \mathrm{P} 4 \mathrm{HB}$. For both cultures, the Na-4HB precursor was not limiting, however, the P4HB content decreased dramatically after $40 \mathrm{~h}$ of cell growth. It seems that most of the cells generated during the late stage had difficulty to accumulate $\mathrm{P} 4 \mathrm{HB}$; leading to a dilution of the $\mathrm{P} 4 \mathrm{HB}$ content caused by cell divisions even if the overall P4HB concentrations were increased. Previously, Song and co-workers have reported similar phenomenon that almost no $\mathrm{P} 4 \mathrm{HB}$ accumulated in newly-produced cells in the late stage during a fed-batch experiment [31]. No explanation could be given. It cannot be caused by the plasmid instability because at the end of the cultivations cells were taken and plated on LB agar with or without ampicillin and were found to maintain at least $90 \%$ of the plasmid (data not shown).

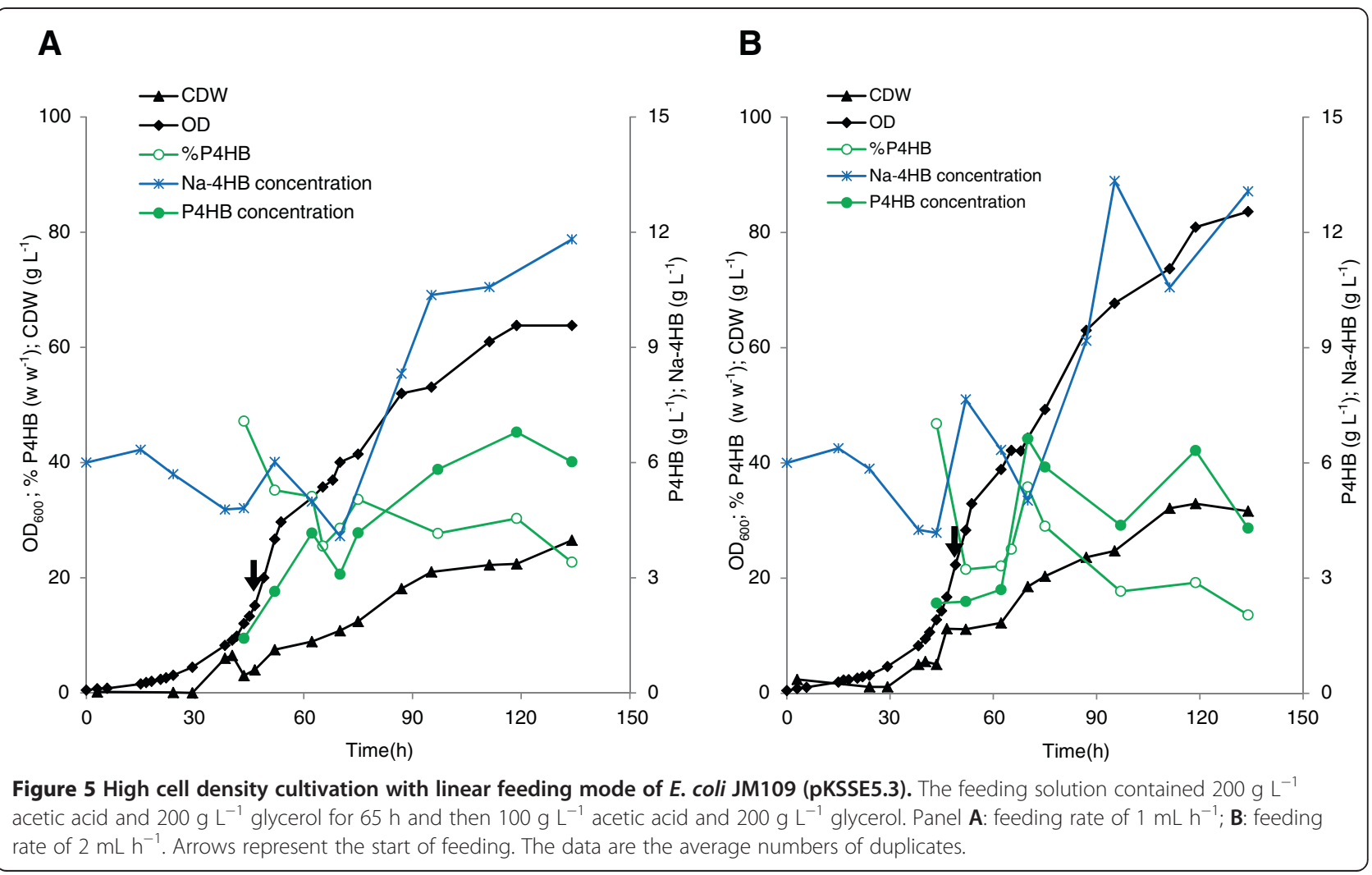




\section{Exponential-feeding}

The batch culture was conducted using modified M9 medium. Three different dilution rates of $0.02 \mathrm{~h}^{-1}, 0.04 \mathrm{~h}^{-1}$ and $0.08 \mathrm{~h}^{-1}$ were tested in cultures $\mathrm{A}, \mathrm{B}$ and $\mathrm{C}$, respectively. The feeding solution used for all three cultures was composed of $40 \mathrm{~g} \mathrm{~L}^{-1} \mathrm{Na}-4 \mathrm{HB}, 300 \mathrm{~g} \mathrm{~L}^{-1}$ glycerol and $20 \mathrm{~g} \mathrm{~L}^{-1}$ acetic acid. The culture A reached a higher maximal $\mathrm{OD}_{600}$ of about 80 after $72.5 \mathrm{~h}$ of cultivation (Figure 6). Cultures $B$ and $C$ showed a similar maximal $\mathrm{OD}_{600}$ of about 100 after $72.5 \mathrm{~h}$ of cultivation (Figure 6). No Na-4HB precursor limitation was observed for any of the three cultivations. The exponential growth stopped at about $53 \mathrm{~h}$, even though glycerol, nitrogen, acetic acid and $\mathrm{Na}-4 \mathrm{HB}$ were found to be still available in the medium based on the measurement described in the Materials and Methods (data not shown). A maximal P4HB content of $34 \% \mathrm{w} \mathrm{w}^{-1}$ and a P4HB concentration of $15 \mathrm{~g} \mathrm{~L}^{-1}$ were obtained for culture A after $72.5 \mathrm{~h}$ of cultivation. These results demonstrate that concomitant addition of acetic acid, glycerol and Na-4HB precursor in E. coli JM109 (pKSSE5.3) can lead to a high productivity by using a slow exponential feeding.

In summary, with the pulse feed strategy an addition of acetic acid at the beginning of the cultivation led to a multi-fold increase in P4HB yield from $9 \%$ to $31 \%\left(\mathrm{w} \mathrm{w}^{-1}\right)$ (Figure 3). A yield of $11.1 \mathrm{~g} \mathrm{~L}^{-1}$ and a P4HB productivity of $0.173 \mathrm{~g} \mathrm{~L}^{-1} \mathrm{~h}^{-1}$ within $64 \mathrm{~h}$ could be achieved. With a linear feeding mode a lower yield was obtained than with pulse feeding (Table 1). The best feeding rate was $1 \mathrm{~mL} \mathrm{~h}^{-1}$, leading to a P4HB yield of $6.8 \mathrm{~g} \mathrm{~L}^{-1}$ and a productivity of $0.058 \mathrm{~g} \mathrm{~L}^{-1} \mathrm{~h}^{-1}$ over $118 \mathrm{~h}$. Exponential feeding led to the maximal yield of $15 \mathrm{~g} \mathrm{~L}^{-1} \mathrm{P} 4 \mathrm{HB}$ in about $72.5 \mathrm{~h}$ with a feeding rate of $0.02 \mathrm{~h}^{-1}$, resulting in a productivity of $0.207 \mathrm{~g} \mathrm{~L}^{-1} \mathrm{~h}^{-1}$ (Table 1). Previously, it has been reported

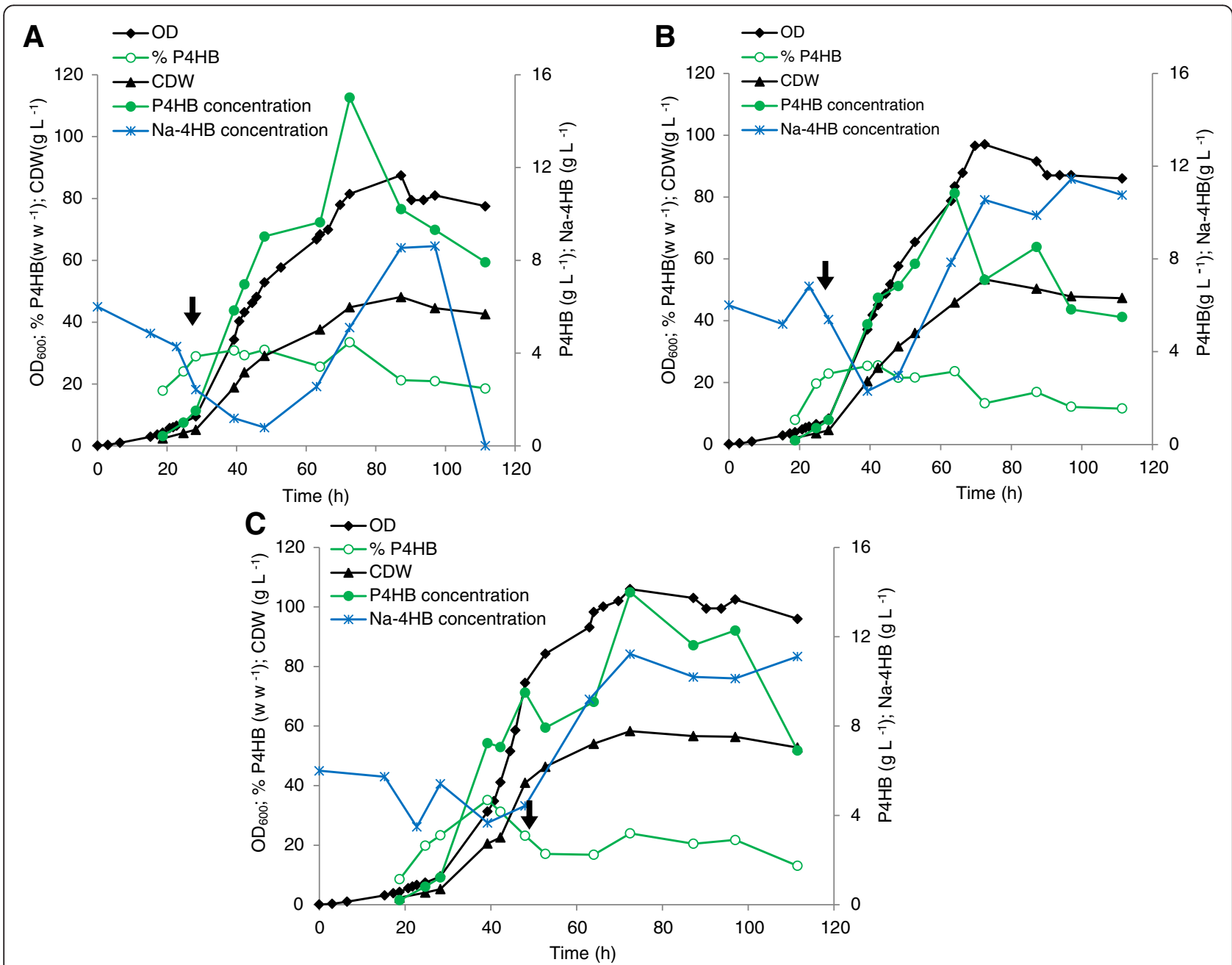

Figure 6 High cell density cultivation with exponential feeding mode. The feeding solution contained $40 \mathrm{~g} \mathrm{~L}^{-1} \mathrm{Na}^{-4 \mathrm{HB}}, 300 \mathrm{~g} \mathrm{~L}^{-1} \mathrm{glycerol}$, and $20 \mathrm{~g} \mathrm{~L}^{-1}$ acetic acid. Controlled feeding rate was set for the cultures $\mathbf{A}, \mathbf{B}$ and $\mathbf{C}$ at $0.02,0.04$ and $0.08 \mathrm{~h}^{-1}$, respectively. Arrows represent the start of feeding. The data are the average numbers of duplicates. 
Table 1 Summary of different feeding modes and their effect on P4HB production during fed-batch cultivations

\begin{tabular}{|c|c|c|c|c|c|c|c|c|}
\hline $\begin{array}{l}\text { Growth substrate/stimulator/ } \\
\text { precursor/media }\end{array}$ & $\begin{array}{l}\text { Feeding } \\
\text { strategy }\end{array}$ & $\begin{array}{l}\text { Culture } \\
\text { time (h) }\end{array}$ & $\mathrm{OD}_{600 \max }$ & $\begin{array}{l}\text { CDW } \\
\left(g^{-1}\right)\end{array}$ & $\begin{array}{l}\text { P4HB content } \\
\%\left(w^{-1}\right)\end{array}$ & $\begin{array}{l}\text { Volumetric yield } \\
\text { P4HB }\left(g^{-1}\right)\end{array}$ & $\begin{array}{l}\text { Productivity } \\
\left(\mathrm{g} \mathrm{L}^{-1} \mathrm{~h}^{-1}\right)\end{array}$ & References \\
\hline \multirow{3}{*}{$\begin{array}{l}\text { Glycerol/acetate/Na-4HB/modified } \\
\text { M9 medium }\end{array}$} & Pulse feed & 64 & 77.9 & 42.8 & 26 & 11.5 & 0.180 & \multirow[t]{3}{*}{ This study } \\
\hline & Linear feed & 118 & 63.8 & 33.8 & 30 & 6.8 & 0.058 & \\
\hline & $\begin{array}{l}\text { Exponential } \\
\text { feed }\end{array}$ & 73 & 81.5 & 43.2 & 33 & 15.0 & 0.207 & \\
\hline Glucose/-/4HB/M9 medium & Pulse feed & 62 & 24.5 & 13.0 & 31 & 4.0 & 0.065 & [31] \\
\hline $\begin{array}{l}\text { Glucose/-/yeast extract/LB } \\
\text { medium }\end{array}$ & Pulse feed & 52 & 21.7 & 11.5 & 68 & 7.8 & 0.150 & [32] \\
\hline
\end{tabular}

that the production of $\mathrm{P} 4 \mathrm{HB}$ homopolymer using glucose as growth substrate and $\mathrm{Na}-4 \mathrm{HB}$ as precursor can reach a final yield of $4.0 \mathrm{~g} \mathrm{~L}^{-1}$ and a $\mathrm{P} 4 \mathrm{HB}$ productivity of $0.065 \mathrm{~g} \mathrm{~L}^{-1} \mathrm{~h}^{-1}$ in $62 \mathrm{~h}$ via a pulse feeding strategy [31]. A recent publication showed that an $E$. coli recombinant JM109SG carrying two plasmids could utilize solely glucose for $\mathrm{P} 4 \mathrm{HB}$ production [32], and a $\mathrm{P} 4 \mathrm{HB}$ yield of $7.8 \mathrm{~g} \mathrm{~L}^{-1}$ and a productivity of $0.150 \mathrm{~g} \mathrm{~L}^{-1} \mathrm{~h}^{-1}$ were obtained by using LB medium containing yeast extract in a pulse feeding fed-batch culture [32]. The productivity of $0.207 \mathrm{~g} \mathrm{~L}^{-1} \mathrm{~h}^{-1}$ obtained in this study is the highest reported so far.

In this study, we also demonstrated that even though the cost of $\mathrm{Na}-4 \mathrm{HB}$ is relative high, it can be significantly reduced by using gamma-butyrolactone as a low-cost precursor for chemical synthesis of $\mathrm{Na}-4 \mathrm{HB}$ (see Methods section). Furthermore, $\mathrm{Na}-4 \mathrm{HB}$ was not used as the growth substrate but the precursor for $\mathrm{P} 4 \mathrm{HB}$, thus only low amount was needed, e.g. a total of about $19 \mathrm{~g} \mathrm{~L}^{-1}$ $\mathrm{Na}-4 \mathrm{HB}$ was added to produce $11 \mathrm{~g} \mathrm{~L}^{-1} \mathrm{P} 4 \mathrm{HB}$ in the case of pulse feeding fed-batch culture (Figure 4).

To further improve the productivity and reduce the cost of $\mathrm{P} 4 \mathrm{HB}$ one of the imperative tasks is to achieve P4HB accumulation in newly-produced cells in the late stage during a fed-batch experiment, thus avoiding the dilution of $\mathrm{P} 4 \mathrm{HB}$ content.

\section{Conclusions}

In this study, we demonstrated that the NZ-amines (amino acids source) in excess abolished P4HB accumulation, suggesting that limitation in certain amino acid pools promotes $\mathrm{P} 4 \mathrm{HB}$ synthesis. This was validated by providing exogenous acetic acid to the cells, which most likely resulted in the reduction of the intracellular amino acid pool. Furthermore, the enhanced $\mathrm{P} 4 \mathrm{HB}$ yield was achieved by both the effective growth of E. coli JM109 (pKSSE5.3) on glycerol and the stimulated P4HB synthesis via exogenous addition of acetic acid. We have developed fermentation strategies for $\mathrm{P} 4 \mathrm{HB}$ production by using glycerol, leading to a productivity of $0.207 \mathrm{~g} \mathrm{~L}^{-1} \mathrm{~h}^{-1}$ $\mathrm{P} 4 \mathrm{HB}$, which is the highest yield for $\mathrm{P} 4 \mathrm{HB}$ production reported so far. This high $\mathrm{P} 4 \mathrm{HB}$ productivity will decrease the total production cost, allowing further development of P4HB applications.

\section{Methods}

\section{Bacterial strain and plasmid}

Escherichia coli JM109 [33] carrying plasmid pKSSE5.3 was used throughout the whole study. pKSSE5.3 harbors the PHA synthase gene (phaC) from Ralstonia eutropha and a 4-hydroxybutyric acid-coenzyme A transferase gene (orfZ) from Clostridium kluyveri [34], and enables E. coli strains to produce $\mathrm{P} 4 \mathrm{HB}$ when $4 \mathrm{HB}$ is supplied in the culture medium. The expression of phaC and orfZ on pKSSE5.3 is driven by their native promoter(s) [34].

\section{Chemicals}

All chemicals were purchased from Sigma-Aldrich (Buchs, Switzerland).

\section{Synthesis of sodium 4-hydroxybutyrate ( $\mathrm{Na}-4 \mathrm{HB})$}

$\mathrm{Na}-4 \mathrm{HB}$ was synthesized by hydrolysis of the corresponding lactone. The synthesis was performed as describe previously $[16,35,36]$. In detail, a $4 \mathrm{M} \mathrm{NaOH}$ solution was prepared and mixed slowly with $4 \mathrm{M}$ of beta-butyrolactone on ice. The reaction mixture was cooled down to room temperature and analyzed by HPLC/MS [16,35]. An almost $100 \%$ conversion of beta-butyrolactone to $\mathrm{Na}-4 \mathrm{HB}$ was achieved.

\section{Media and cultivation conditions \\ Shake flasks experiments}

Growth studies were performed in $1 \mathrm{~L}$ shake flasks containing $200 \mathrm{~mL}$ of modified E2 medium and $10 \mathrm{~g} \mathrm{~L}^{-1}$ of carbon source glycerol. One $\mathrm{g} \mathrm{L}^{-1}$ of NZ-amines, $100 \mu \mathrm{g} \mathrm{mL}^{-1}$ ampicillin and $4 \mathrm{~g} \mathrm{~L}^{-1}$ of $\mathrm{Na}-4 \mathrm{HB}$ were added at the beginning of the cultivation. NZ-amines are casein enzymatic hydrolysates with a total amino acid content of approximately $0.89 \mathrm{~g} \mathrm{~g}^{-1}$. Cultures were incubated at $32^{\circ} \mathrm{C}$ and $150 \mathrm{rpm}$ based on our previous study [16]. Modified E2 medium was composed of the following components: $\mathrm{NaNH}_{4} \mathrm{HPO}_{4} \cdot 4 \mathrm{H}_{2} \mathrm{O} 3.5 \mathrm{~g} \mathrm{~L}^{-1}, \mathrm{KH}_{2} \mathrm{PO}_{4} 3.7 \mathrm{~g} \mathrm{~L}^{-1}$ and $\mathrm{K}_{2} \mathrm{HPO}_{4} 7.5 \mathrm{~g} \mathrm{~L}^{-1}$ dissolved in distilled water. One $\mathrm{mL} \mathrm{L}^{-1}$ of $1 \mathrm{M} \mathrm{MgSO}_{4} \cdot 7 \mathrm{H}_{2} \mathrm{O}$ and $1 \mathrm{~mL} \mathrm{~L}^{-1}$ of trace elements 
(TE) dissolved in $1 \mathrm{M} \mathrm{HCl}$ were added. TE contains $\mathrm{FeSO}_{4} \cdot 7 \mathrm{H}_{2} \mathrm{O} 2.78 \mathrm{~g} \mathrm{~L}^{-1}, \mathrm{CaCl}_{2} \cdot 2 \mathrm{H}_{2} \mathrm{O} 1.47 \mathrm{~g} \mathrm{~L}^{-1}, \mathrm{MnCl}_{2}$. $4 \mathrm{H}_{2} \mathrm{O} 1.98 \mathrm{~g} \mathrm{~L}^{-1}, \mathrm{CoCl}_{2} \cdot 6 \mathrm{H}_{2} \mathrm{O} 2.38 \mathrm{~g} \mathrm{~L}^{-1}, \mathrm{CuCl}_{2} \cdot 2 \mathrm{H}_{2} \mathrm{O}$ $0.17 \mathrm{~g} \mathrm{~L}^{-1}$, and $\mathrm{ZnSO}_{4} \cdot 7 \mathrm{H}_{2} \mathrm{O} 0.29 \mathrm{~g} \mathrm{~L}^{-1}$. LB was used as the preculture medium to inoculate the main culture to an initial $\mathrm{OD}_{600}$ between 0.2 and 0.3 .

\section{Bioreactor experiments}

\section{Experiments of identification of influencing factors in batch} culture

E. coli JM109 (pKSSE5.3) cells were grown at $32^{\circ} \mathrm{C}$ in $1 \mathrm{~L}$ bioreactors (Infors AG, Bottmingen, Switzerland) containing modified E2 medium supplemented with $10 \mathrm{~g} \mathrm{~L}^{-1} \mathrm{xy}$ lose, $4 \mathrm{~g} \mathrm{~L}^{-1} \mathrm{Na}-4 \mathrm{HB}, 1 \mathrm{~g} \mathrm{~L}^{-1} \mathrm{NZ}$-amines and $0.015 \mathrm{~g} \mathrm{~L}^{-1}$ thiamine. Preculture medium had the same composition as the one for the main culture. The initial $\mathrm{OD}_{600}$ value in bioreactors was always between 0.1 and 0.3 units. Temperature was controlled at $32^{\circ} \mathrm{C}$ and $\mathrm{pH}$ was maintained at 7.0 by automated addition of $25 \% \mathrm{NaOH}$ or $2 \mathrm{M} \mathrm{H}_{2} \mathrm{SO}_{4}$. The dissolved oxygen tension was monitored continuously with an oxygen probe and maintained at $30 \%$ of oxygen saturation.

\section{High cell density culture experiments}

In order to improve the productivity, high cell density cultivations were performed using E. coli JM109 (pKSSE5.3). Modified M9 medium instead of modified E2 medium was used in these studies because modified M9 medium was reported to be suitable for high cell density culture of E. coli JM109 [37]. Modified M9 medium contained $4 \mathrm{~g} \mathrm{~L}^{-1}$ $\left(\mathrm{NH}_{4}\right)_{2} \mathrm{HPO}_{4}, 13.3 \mathrm{~g} \mathrm{~L}^{-1} \mathrm{KH}_{2} \mathrm{PO}_{4}, 1 \mathrm{~g} \mathrm{~L}^{-1}\left(\mathrm{NH}_{4}\right)_{2} \mathrm{SO}_{4}$, $20 \mathrm{~g} \mathrm{~L}^{-1}$ glycerol, $6 \mathrm{~g} \mathrm{~L}^{-1} \mathrm{Na}-4 \mathrm{HB}$, and $0.5 \mathrm{~g} \mathrm{~L}^{-1}$ NZ-amines. After autoclaving the medium, $10 \mathrm{~mL} \mathrm{~L}^{-1}$ of trace elements composed of $2.5 \mathrm{~g} \mathrm{~L}^{-1} \mathrm{CaCl}_{2}, 0.075 \mathrm{~g} \mathrm{~L}^{-1}$ $\mathrm{CuCl}_{2} \cdot 4 \mathrm{H}_{2} \mathrm{O}, 3.525 \mathrm{~g} \mathrm{~L}^{-1} \mathrm{FeCl}_{3} \cdot 4 \mathrm{H}_{2} \mathrm{O}, 0.65 \mathrm{~g} \mathrm{~L}^{-1} \mathrm{Zn}$ $\left(\mathrm{CH}_{3} \mathrm{COO}\right)_{2}, 0.75 \mathrm{~g} \mathrm{~L}^{-1} \mathrm{MnCl}_{2} \cdot 4 \mathrm{H}_{2} \mathrm{O}, 0.125 \mathrm{~g} \mathrm{~L}^{-1} \mathrm{CoCl}_{2}$. $6 \mathrm{H}_{2} \mathrm{O}, 0.15 \mathrm{~g} \mathrm{~L}^{-1} \mathrm{H}_{3} \mathrm{BO}_{3}, 0.125 \mathrm{~g} \mathrm{~L}^{-1} \mathrm{NaMoO}_{4} \cdot 2 \mathrm{H}_{2} \mathrm{O}$ and $0.625 \mathrm{~g} \mathrm{~L}^{-1} \mathrm{Na}_{2}$ EDTA were added to the medium. In addition, $5 \mathrm{~mL} \mathrm{~L}^{-1}$ of $1 \mathrm{M} \mathrm{MgSO}_{4} \cdot 7 \mathrm{H}_{2} \mathrm{O}, 0.015 \mathrm{~g} \mathrm{~L}^{-1}$ thiamine, and $100 \mathrm{mg} \mathrm{L}^{-1}$ ampicillin were filter sterilized separately and added to the bioreactors before inoculation. Preculture medium had the same composition as the one for the main culture. The initial $\mathrm{OD}_{600}$ value in bioreactors was always between 0.1 and 0.3 units. Temperature was controlled at $32^{\circ} \mathrm{C}$ and $\mathrm{pH}$ was maintained at 7.0 by automated addition of $7.7 \mathrm{M} \mathrm{NH}_{4} \mathrm{OH}$ or $2 \mathrm{M} \mathrm{H}_{2} \mathrm{SO}_{4}$. The dissolved oxygen tension was monitored continuously with an oxygen probe and maintained at $30 \%$ of oxygen saturation.

For exponential feedings, the substrate feeding rate $(F)$ for controlling the specific growth rate $(\mu)$ was determined as follows with neglecting the carbon substrate consumption for cell energy maintenance. To get a time-dependent exponential feed, it is necessary to achieve a constant $\mu$ that is lower than $\mu_{\max }$. We started from the mass balance on the limiting substrate, which in our case is the growth carbon substrate (glycerol). The consumption of growth limiting substrate concentration according to the time can be expressed by:

$$
\frac{d S}{d t}=\frac{F}{V}\left(s_{0}-s\right)-q_{s} x
$$

where $s_{0}$ is the limiting substrate concentration $\left(\mathrm{g} \mathrm{L}^{-1}\right)$ in feeding medium and $s$ is the actual growth limiting substrate concentration $\left(\mathrm{g} \mathrm{L}^{-1}\right)$ in culture broth, $Y_{X / S}$ is the growth yield $\left(\mathrm{g} \mathrm{g}^{-1}\right)$ for the limiting substrate and $q_{s}$ is the specific substrate consumption rate $\left(\mathrm{g} \mathrm{g}^{-1} \mathrm{~h}^{-1}\right)$.

Because the cell density in the fed-batch is very high and $s_{0}$ therefore consumed rapidly, it can be stated that $s<<s_{0}$ and $\frac{d s}{d t} \approx 0$. Consequently, equation 1 can be modified to:

$$
F=\frac{q_{s}(x V)}{s_{0}}
$$

The biomass concentration $(x)$ and the volume of the culture $(V)$ increased with time, leading to:

$$
(x V)_{t}=\left(x_{0} V_{0}\right) e^{\mu t}
$$

Where $x_{0}$ and $V_{\mathrm{o}}$ are starting biomass concentration and the initial volume of culture, respectively. Hence, the flow rate which enables recombinant E. coli to grow at a constant $\mu$ is obtained in equation (4) by combining the equations (2) and (3).

$$
F(t)=\frac{q_{s}}{s_{0}}\left(x_{0} V_{0}\right) e^{\mu t}
$$

This is equivalent to:

$$
F(t)=F_{0} e^{\mu t}
$$

This means one can formulate the starting flow condition $F_{\mathrm{o}}$ at $t=0 \mathrm{~h}$ as follows:

$$
\begin{aligned}
& F_{0}=\frac{\mu}{s_{0} Y_{X / S}} x_{0} \\
& F_{0}=\mu V
\end{aligned}
$$

The exponential feeding technique allows controlling the overflow metabolism of recombinant $E$. coli in a fedbatch process. This technique makes it possible to grow the culture at a constant specific growth rate and consequently the yield coefficient $Y_{X / S}$ remains constant.

\section{Test of plasmid stability}

Cells at the end of cultivation were collected and a serial dilution of the cell suspension was prepared. The suspensions were plated on the LB agar plate with or without ampicillin. The plates were incubated overnight at $37^{\circ} \mathrm{C}$ 
and the colony numbers on plates with and without ampicillin were counted and compared.

\section{Analytical methods \\ Cell concentration}

Growth of bacterial cells was followed by measuring optical density at $600 \mathrm{~nm}\left(\mathrm{OD}_{600}\right)$ using a UV-visible spectrophotometer (Genesys 6, ThermoSpectronic, Switzerland).

Cell dry weight (CDW) was determined using $2 \mathrm{~mL}$ pre-weighted Eppendorf tubes. Two mL culture broth were added into the tube and centrifuged at $10^{\prime} 000 \mathrm{~g}$ for $2 \mathrm{~min}$. The cell pellet was washed once with water. Cells were spun down again and the cell pellet was dried overnight at $100^{\circ} \mathrm{C}$, cooled down to room temperature in a desiccator and weighed. The weight difference was used to determine the quantity of biomass per culture volume.

\section{PHA content}

To determine the PHA content and composition, the culture was centrifuged $\left(8^{\prime} 500 \mathrm{~g}, 4^{\circ} \mathrm{C}, 15 \mathrm{~min}\right)$ and the cell pellet was washed once with water and lyophilized for 48 hours. Biomass in the range of $20-50 \mathrm{mg}$ was added to Pyrex vials. Then, $2 \mathrm{ml}$ of $15 \% \mathrm{v} \mathrm{v}^{-1} \mathrm{H}_{2} \mathrm{SO}_{4}$ in methanol was added and mixed. Furthermore, $2 \mathrm{ml}$ of methylene chloride containing benzoic acid $\left(0.1 \mathrm{~g} \mathrm{~L}^{-1}\right)$ as internal standard were added. The suspension was boiled at $100^{\circ} \mathrm{C}$ for $2.5 \mathrm{~h}$ in an oven. The samples were cooled on ice, and $1 \mathrm{ml}$ of distilled water was added in order to extract the cell debris into the aqueous phase. The solution was mixed by vortexing for $1 \mathrm{~min}$. The complete (upper) water phase was discarded, including droplets hanging on the tube wall. The remaining methylene chloride phase was dried and neutralized by adding $\mathrm{Na}_{2} \mathrm{SO}_{4}$ and $\mathrm{Na}_{2} \mathrm{CO}_{3}$ powder, and $200 \mu \mathrm{l}$ of the organic phase were filtered using a solvent resistant filter (PTFE, $0.45 \mu \mathrm{m}$ ) and transferred to a GC sample vial. Samples were analyzed using gas chromatography (GC) (A200s, Trace GC 2000 series, Fisons Instruments, Rodano, Italy) equipped with a polar fused silica capillary column (Supelcowax-10: length $30 \mathrm{~m}$; inside diameter $0.31 \mathrm{~mm}$; film thickness $0.5 \mu \mathrm{m}$; Supelco, Sigma-Aldrich, Buchs, Switzerland) [38]. The methylation of $\mathrm{P} 4 \mathrm{HB}$ resulted in 3 distinct peaks representing the methylester of $4 \mathrm{HB}, \gamma$-butyrolactone and the methyl ether of $4 \mathrm{HB}$, respectively, which were also obtained if only Na-4HB was subjected to methanolysis. These three peaks were also observed by others when analyzing P4HB homopolymers [16,34,39].

\section{Evaluation of glycerol limitation}

The dissolved oxygen tension $\left(\mathrm{pO}_{2}\right)$ was used as an indicator for glycerol consumption during fed-batch cultures [40]. This is based on the fact that whenever the substrate in the medium is about to run out and thus becomes a limiting factor, the $\mathrm{pO}_{2}$ increases rapidly. When the carbon substrate is added to the culture, $\mathrm{pO}_{2}$ decreases to its former level.

\section{Measurement of nitrogen}

$\mathrm{NH}_{4}^{+}$-nitrogen content was measured using an ammonium test kit following the manufacturer instruction (Merck KGaA, 64271 Darmstadt, Germany). The detection range was from 0.01 to $3.0 \mathrm{NH}^{+}-\mathrm{N} \mathrm{mg} \mathrm{L}{ }^{-1}$, above which dilution with distilled water was needed.

\section{Acetate and $\mathrm{Na}-4 \mathrm{HB}$ measurements}

Acetate and $\mathrm{Na}-4 \mathrm{HB}$ were measured by HPLC/MS (Agilent 1000 Series, Santa Clara, United States for the HPLC unit, and Bruker Daltonics esquire HCT, Bremen, Germany for the MS unit). Supernatant resulting from culture centrifugation at $10^{\prime} 000 \mathrm{~g}$ for $2 \mathrm{~min}$ was diluted to 0.01 to $0.1 \mathrm{mM}$ with distilled water and loaded on a reversed phase C18 column (Gemini C18 5 micron, $250 \mathrm{~mm} \times 4.60 \mathrm{~mm}$, Phenomenex, U.K.). A gradient of diluted formic acid $\left(0.1 \% \mathrm{v} \mathrm{v} \mathrm{v}^{-1}\right.$ in water) to $100 \%$ acetonitrile mixed with $0.1 \% \mathrm{v} \mathrm{v}^{-1}$ formic acid was applied as the mobile phase. The flow rate was $0.8 \mathrm{~mL} \mathrm{~min}^{-1}$ and the gradient was completed after 25 minutes. The peaks were detected by electrospray ionization (ESI) in negative mode [35]. The standard curves for acetate and $\mathrm{Na}-4 \mathrm{HB}$ were recorded in the range of 0.01 to $1 \mathrm{~g} \mathrm{~L}^{-1}$ and 0.01 to $0.2 \mathrm{~g} \mathrm{~L}^{-1}$, respectively.

\section{Reproducibility}

In this study, for each batch culture at least two independent experiments were performed, for each fed-batch culture at least three independent experiments were performed. The absolute values of cell density and P4HB content obtained from the independent experiments varied, which is not surprising for biological systems. This could be caused by slight differences in inoculum, cultivation conditions, sampling, and etc. However, the cell growth and P4HB synthesis exhibited same patterns in the same set of independent experiments. In this report the results obtained from one independent experiment were presented. Each individual sample was measured in duplicates. The data presented here are the average numbers.

\section{Competing interests}

The authors declare that they have no competing interests.

\section{Authors' contributions}

SLM designed and performed the experiments, prepared and revised the manuscript. MZ and TE participated in designing the experiment and in revising the final manuscript. LTM revised the final manuscript. QR designed and supervised the experiments, prepared and revised the manuscript. All authors read and approved the final manuscript.

\section{Acknowledgement}

We thank Melisa Novelli for technical assistances. We thank Prof. Guogiang Chen (Tsinghua University) for kindly providing the plasmid pKSSE5.3. The Swiss Commission for Technology and Innovation (CTI) is acknowledged for the financial support of this work through project number 12409.2 PFLS-LS. 


\section{Author details}

1 Laboratory for Bioactive Materials, Swiss Federal Laboratories for Materials Science and Technology (Empa), Lerchenfeldstrasse 5, St. Gallen CH-9014, Switzerland. ${ }^{2}$ Swiss Federal Institute of Technology Zurich (ETH), Environmental Sciences, Rämistrasse 101, Zurich 8092, Switzerland. ${ }^{3}$ Biotechnology, HES-SO Valais Wallis, Rue du Rawyl 64, P.O.B. 2134, Sion CH-1950, Switzerland. ${ }^{4}$ Environmental Microbiology, Swiss Federal Institute of Aquatic Science and Technology (Eawag), Überlandstrasse 133, P.O. Box 610, Dübendorf CH-8600, Switzerland.

Received: 18 June 2014 Accepted: 26 August 2014 Published: 31 August 2014

\section{References}

1. Brandl H, Bachofen R, Mayer J, Wintermantel E: Degradation and applications of polyhydroxyalkanoates. Can J Microbiol 1995, 41:143-153.

2. Chen GQ: A microbial polyhydroxyalkanoates (PHA) based bio- and materials industry. Chem Soc Rev 2009, 38(8):2434-2446.

3. Madison LL, Huisman GW: Metabolic engineering of poly(3Hydroxyalkanoates): from DNA to plastic. Microbiol Mol Biol Rev 1999, 63(1):21-53.

4. Zinn M, Witholt B, Egli T: Occurrence, synthesis and medical application of bacterial polyhydroxyalkanoate. Adv Drug Deliver Rev 2001, 53(1):5-21.

5. Chen GQ, Wu Q: Microbial production and applications of chiral hydroxyalkanoates. Appl Microbiol Biotechnol 2005, 67:592-599.

6. Ren Q, Ruth K, Thöny-Meyer L, Zinn M: Enatiomerically pure hydroxycarboxylic ac-ids: current approaches and future perspectives. Appl Microbiol Biotechnol 2010, 87:41-52.

7. Steinbüchel A, Valentin HE: Diversity of bacterial polyhydroxyalkanoic acids. FEMS Microbiol Lett 1995, 128(3):219-228.

8. Ward PG, O'Connor KE: Bacterial synthesis of polyhydroxyalkanoates containing aromatic and aliphatic monomers by Pseudomonas putida CA-3. Int J Biol Macromol 2005, 35:127-133.

9. Martin DP, Williams SF: Medical applications of poly-4-hydroxybutyrate: a strong flexible absorbable biomaterial. Biochem Eng J 2003, 16(2):97-105.

10. Nelson T, Kaufman E, Kline J, Sokoloff L: The extraneural distribution of gamma-hydroxybutyrate. J Neurochem 1981, 37(5):1345-1348.

11. Opitz F, Schenke-Layland K, Richter W, Martin DP, Degenkolbe I, Wahlers T, Stock UA: Tissue engineering of ovine aortic blood vessel substitutes using applied shear stress and enzymatically derived vascular smooth muscle cells. Ann Biomed Eng 2004, 32(2):212-222.

12. Shojaosadati SA, Kolaei SMV, Babaeipour V, Farnoud AM: Recent advances in high cell density cultivation for production of recombinant protein Iran J Biotechnol 2008, 6:63-84.

13. Restaino OF, Bhaskar U, Paul P, Li L, De Rosa M, Dordick JS, Linhardt RJ: High cell density cultivation of a recombinant $E$. coli strain expressing a key enzyme in bioengineered heparin production. Appl Microbiol Biotechnol 2013, 97:3893-3900.

14. Yamanè T, Shimizu S: Fed-batch techniques in microbial processes. In Adv Biochem Eng Biotech. Edited by Fiechter A. New York: Springer-Verlag; 1984:147-194.

15. Korz DJ, Rinas U, Hellmuth K, Sanders EA, Deckwer WD: Simple fed-batch technique for high cell density cultivation of Escherichia coli. J Biotechnol 1995, 39(1):59-65.

16. Le Meur S, Zinn M, Egli T, Thöny-Meyer L, Ren Q: Poly(4-hydroxybutyrate) (P4HB) production in recombinant Escherichia coli: P4HB synthesis is uncoupled with cell growth. Microb Cell Fact 2013, 12:123.

17. Lee SY, Lee KM, Chang HN, Steinbüchel A: Comparison of recombinant Escherichia coli strains for synthesis and accumulation of poly-(3-hydroxybutyric acid) and morphological changes. Biotechnol Bioeng 1994, 44(11):1337-1347.

18. Song S, Park C: Utilization of D-ribose through D-xylose transporter. FEMS Microbiol Lett 1998, 163:255-261.

19. Thompson JC, He BB: Characterization of crude glycerol from biodiesel production from multiple feedstocks. Appl Eng Agric 2006, 22(2):261-265.

20. da Silva GP, Mack M, Contiero J: Glycerol: a promising and abundant carbon source for industrial microbiology. Biotechnol Adv 2009, 27:30-39.

21. Lee SY: High cell-density culture of Escherichia coli. Trends Biotechnol 1996, 14(3):98-105.
22. Waegeman $\mathrm{H}$, Soetaert $\mathrm{W}$ : Increasing recombinant protein production in Escherichia coli through metabolic and genetic engineering. J Ind Microbiol Biotechnol 2011, 38(12):1891-1910.

23. Clomburg JM, Gonzalez R: Biofuel production in Escherichia coli: the role of metabolic engineering and synthetic biology. Appl Microbiol Biotechnol 2010, 86(2):419-434.

24. Palmeri R, Pappalardo F, Fragalà M, Tomasello M, Damigella A, Catara AF: Polyhydroxyalkanoates (PHAs) production through conversion of glycerol by selected strains of Pseudomonas mediterranea and Pseudomonas corrugata. Chem Eng Trans 2012, 27:121-126.

25. Wang FL, Lee SY: Poly(3-hydroxybutyrate) production with high productivity and high polymer content by a fed-batch culture of Alcaligenes latus under nitrogen limitation. Appl Environ Microbiol 1997 63(9):3703-3706.

26. Kämpf MM, Thöny-Meyer L, Ren Q: Biosynthesis of poly(4-hydroxybutyrate) in recombinant Escherichia coli grown on glycerol is stimulated by propionic acid. Int J Biol Macromol 2014, http://dx.doi.org/10.1016/j. ijbiomac.2014.04.023.

27. Roe AJ, O'Byrne C, McLaggan D, Booth IR: Inhibition of Escherichia coli growth by acetic acid: a problem with methionine biosynthesis and homocysteine toxicity. Microbiology-Sgm 2002, 148:2215-2222.

28. Luli GW, Strohl WR: Comparison of growth, acetate production, and acetate inhibition of Escherichia coli strains in batch and fed-batch fermentations. Appl Environ Microbiol 1990, 56(4):1004-1011.

29. Kim JS, Lee BH, Kim BS: Production of poly(3-hydroxybutyrate-co-4hydroxybutyrate) by Ralstonia eutropha. Biochem Eng J 2005, 23(2):169-174.

30. Lin H, Castro NM, Bennett GN, San KY: Acetyl-CoA synthetase overexpression in Escherichia coli demonstrates more efficient acetate assimilation and lower acetate accumulation: a potential tool in metabolic engineering. Appl Microbiol Biotechnol 2006, 71(6):870-874

31. Song SS, Hein S, Steinbüchel A: Production of poly(4-hydroxybutyric acid) by fed-batch cultures of recombinant strains of Escherichia coli. Biotechnol Lett 1999, 21(3):193-197.

32. Zhou XY, Yuan XX, Shi ZY, Meng DC, Jiang WJ, Wu LP, Chen JC, Chen GQ Hyperproduction of poly(4-hydroxybutyrate) from glucose by recombinant Escherichia coli. Microb Cell Fact 2012, 11(1):54.

33. Yanisch-Perron C, Vieira J, Messing J: Improved M13 phage cloning vectors and host strains: nucleotide sequences of the M13mp18 and pUC19 vectors. Gene 1985, 33(1):103-119.

34. Hein S, Söhling B, Gottschalk G, Steinbüchel A: Biosynthesis of poly (4-hydroxybutyric acid) by recombinant strains of Escherichia coli. FEMS Microbiol Lett 1997, 153:411-418.

35. Ren Q, Grubelnik A, Hoerler M, Ruth K, Hartmann R, Felber H, Zinn M: Bacterial poly(hydroxyalkanoates) as a source of chiral hydroxyalkanoic acids. Biomacromolecules 2005, 6(4):2290-2298.

36. Marvel CS, Birkhimer ER: The preparation of the sodium salts of omega-hydroxybutyric, -valeric and -caproic acids. J Am Chem Soc 1929 51:260-262

37. Ren Q, Henes B, Fairhead M, Thöny-Meyer L: High level production of tyrosinase in recombinant Escherichia coli. BMC Biotechnol 2013, 13:18.

38. Braunegg G, Sonnleitner B, Lafferty RM: A rapid gas chromatographic method for the determination of poly-3-hydroxybutyric acid in microbial biomass. Eur J Appl Microbiol Biotechnol 1978, 6:29-37.

39. Valentin HE, Zwingmann G, Schonebaum A, Steinbüchel A: Metabolic pathway for biosynthesis of poly(3-hydroxybutyrate-co-4-hydroxybutyrate) from 4-hydroxybutyrate by Alcaligenes eutrophus. Eur I Biochem 1995, 227(1-2):43-60.

40. Cutayar CM, Poillon D: High cell density culture of E. coli in a fed-batch system with dissolved oxygen as substrate feed indicator. Biotechnol Lett 1989, 11:155-160.

doi:10.1186/s12934-014-0131-2

Cite this article as: Le Meur et al: Improved productivity of poly (4hydroxybutyrate) (P4HB) in recombinant Escherichia coli using glycerol as the growth substrate with fed-batch culture. Microbial Cell Factories 2014 13:131. 